\title{
Analisis Implementasi Metode Semantic Similarity untuk Pengukuran Kemiripan Makna Antar Kalimat
}

\author{
Gandhis Ulta Abriania ${ }^{1, *}$, Muhammad Ainul Yaqin ${ }^{2}$ \\ Jurusan Teknik Informatika Universitas Islam Negeri Maulana Malik Ibrahim, Indonesia \\ ${ }^{1}$ gandhisultaabriani10@gmail.com; ${ }^{2}$ yaqinov@ti.uin-malang.ac.id \\ * corresponding author
}

ARTIKEL INFO

Article history

Diterima: 27 Oktober 2019

Direvisi: 25 November 2019

Diterbitkan: 30 Desember 2019

Keywords

Word Similarity

WordNet

Word Similarity for Java (WS4J)

Wu Palmer

Sentence Similarity

\section{ABSTRAK}

Perhitungan sentence similarity dilakukan dengan menghitung nilai kemiripan antar katanya. Pada beberapa penelitian yang telah dilakukan sebelumnya, perhitungan sentence similarity hanya berhenti pada nilai kemiripan antar kata pada kalimat sebagai nilai akhirnya. Sedangkan pada perhitungan sentence similarity bertujuan untuk menghitung nilai kemiripan keseluruhan dalam bentuk kalimat menjadi satu nilai kemiripan secara utuh sebagai hasil akhir. Perhitungan word similarity berdasarkan contextual-nya dihitung menggunakan Word Similarity for Java (WS4J) dengan tiga pendekatan yaitu wu palmer, lin, dan path. Menghitung nilai kemiripan menggunakan WS4J hanya dapat diuraikan berdasarkan kemiripan antar kata, sehingga dilakukan pembobotan menggunakan metode Analytical Hierarchy Process (AHP). Ada dua aspek yang digunakan sebagai kriteria pada perhitungan AHP untuk menentukan nilai bobot kriterianya yaitu noun, dan verb. Dari hasil tersebut, kemudian dilakukan pembobotan dengan mengakumulasikan matriks nilai word similarity dengan nilai bobot kriteria masing-masing untuk memperoleh nilai sentence similarity.

\section{PENDAHULUAN}

Kalimat merupakan serangkaian kata yang terdiri dari beberapa jenis struktur dasar yang menyusunnya. Serangkaian kata dapat disebut sebagai kalimat apabila minimal memiliki susunan struktur dasar yaitu noun, dan verb. Selain dua struktur dasar tersebut, terdapat beberapa kelas lain yang menyusun suatu kalimat seperti; adjective, adverb, conjunction, modal, to, prepotition, pronoun, determiner, dan particle. Dalam perbendaharaan bahasa terdapat kumpulan kata yang di dalamnya ada berbagai kata yang memiliki kemiripan makna atau sering disebut dengan sinonim. Dalam membandingkan kemiripan antar kata yang satu dengan yang lain disesuaikan dengan masing-masing jenis kelas katanya. Perbandingan antar kata hanya dapat dilakukan dengan kata yang memiliki jenis kelas kata yang sama. Sedangkan kemiripan makna kalimat yaitu gabungan dari kemiripan antar kata. Untuk mengetahui kedekatan makna antar kalimat maka dapat dilakukan dengan cara menghitung nilai kemiripan makna antar kalimat tersebut. Perhitungan sentence similarity merupakan metric dasar untuk mengukur tingkat kemiripan antar sepasang kalimat [1]. Sentence similarity termasuk dalam perhitungan semantic similarity. Ada dua kategori dalam perhitungan sentence similarity yaitu pengukuran berdasarkan syntactical dan lexical. Pendekatan syntactic ini untuk menghitung semantic similarity menggunakan hubungan ketergantungan sintaksis untuk membangun gambaran yang lebih komprehensif tentang makna teks yang dibandingkan, 
dan mengidentifikasi apakah kata benda adalah dianggap subjek atau objek dari kata kerja. Pendekatan lexical untuk menghitung semantic similarity pada term [1][2].

Pada penelitian-penelitian yang telah dilakukan sebelumnya, hanya mengukur kemiripan kata pada kalimat [4][5]. Hasil akhir tidak berupa satu nilai utuh secara keseluruhan yang dinyatakan sebagai nilai sentence similarity. Dalam penelitian ini akan mengukur nilai sentence similarity yang menghasilkan satu nilai utuh sebagai hasil akhir yang dinyatakan sebagai nilai dari sentence similarity. Dalam perhitungan semantic similarity terdapat beberapa pendekatan yang dihitung berdasarkan string dan contextualnya [6][7]. Pada penelitian ini menggunakan perhitungan kemiripan berdasarkan contextual atau makna antar katanya menggunakan Word Similarity for Java (WS4J). Pendekatan yang digunakan untuk menghitung nilai word similarity yaitu pendekatan $W u$ Palmer (WUP), path, dan lin [2][8][9]. Setelah itu menentukan nilai pembobotan kata pada kalimat menggunakan metode Analytical Hierarchy Process (AHP). Kriteria yang digunakan untuk mennetukan nilai bobotnya yaitu noun, dan verb. Noun, dan verb merupakan dua jenis kelas kata yang terhitung nilai kemiripannya pada WS4J. Setelah diketahui nilai word similarity dan nilai bobot kriterianya, kemudian menghitung matriks nilai kemiripan kata dengan nilai bobot masing-masing kriteria yang sesuai untuk menentukan nilai sentence similarity.

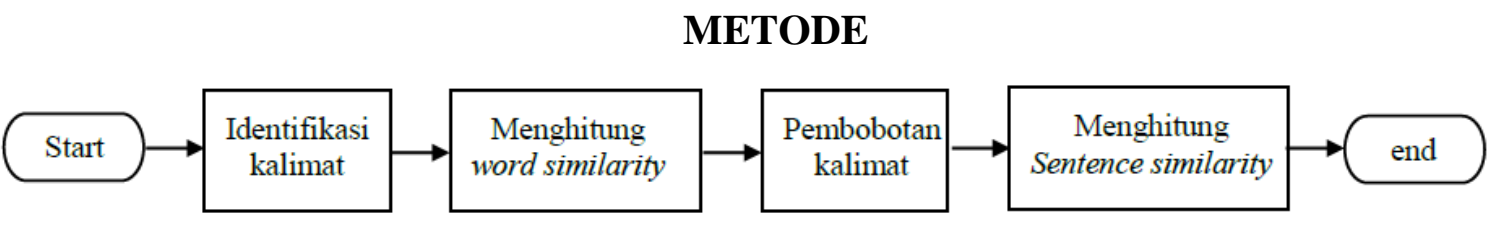

Gambar 1. Prosedur Penelitian

Gambar 1 merupakan alur proses penelitian mulai dari identifikasi kalimat hingga menghitung nilai kemiripan kalimat sebagai tujuan dari penelitian ini.

\section{Identifikasi Kalimat}

Identifikasi kalimat merupakan tahap pertama yang dilakukan dalam proses perhitungan kemiripan kalimat. Tahap ini yakni memilah kalimat sesuai dengan jenis atau kriteria katanya. Proses yang dilakukan untuk menentukan jenis kata pada kalimat yaitu menggunakan wordNet. Dalam penelitian ini menggunakan WS4J (WordNet Similarity for Java) yang juga digunakan untuk menghitung nilai kemiripan kata. Dalam perhitungan kemiripan menggunakan WS4J, kalimat diuraikan menjadi beberapa kelas kata.

Tabel 1. Kelas kata yang terdaftar pada WS4J

\begin{tabular}{|l|l|l|l|}
\hline \multicolumn{1}{|c|}{ Label } & \multicolumn{1}{|c|}{ Keterangan } & Label & \multicolumn{1}{c|}{ Keterangan } \\
\hline DT & Determiner & VB & Verb, base form \\
\hline IN & Prepotition & VBD & Verb, past tense \\
\hline JJ & Adjective & VBN & Verb, past participle \\
\hline NN & Noun, singular & VBZ & Verb, singular \\
\hline NNS & Noun, plural & VBP & Verb, plural \\
\hline RB & Adverb & PRP & Pronoun \\
\hline RP & Particle & CC & Conjuntion \\
\hline TO & To & MD & Modal \\
\hline
\end{tabular}

Tabel 1 menunjukkan beberapa daftar kelas kata yang terdapat pada WS4J. Dari beberapa kelas kata pada tabel 1 tersebut hanya kelas noun, dan verb yang terhitung nilai 
kemiripannya, sehingga pada tahap identifikasi kalimat ini hanya memilah kata pada kalimat berdasar jenis noun, dan verb saja yang kemudian digunakan pada tahan perhitungan word similarity. Berikut adalah contoh kalimat yang digunakan:

- Sentence $1:$ the adviser accepted an invitation to fill a business seminar

- Sentence 2 : the orator found an invitation to fill a business seminar

\section{Menghitung Word Similarity}

Word Similarity merupakan perhitungan kemiripan antar kata yang dapat dihitung menggunakan WS4J dengan berbagai pendekatan. Ada tiga pendekatan yang digunakan dalam penelitian ini antara lain pendekatan Wu Palmer, Lin, dan Path.

\section{Metode Wu palmer}

$W u$ palmer merupakan algortima kemiripan semantik, sehingga mampu mengukur derajat keterkaitan atau relevansi antar dokumen ataupun antar term [10][11]. Wu palmer mampu mengukur derajat kemiripan makna semantik antar kata.

$$
\operatorname{sim}_{\text {vup }}(s 1, s 2)=\frac{2 x \operatorname{depth}(\text { LCS })}{(\operatorname{depth}(s 1)+\operatorname{depth}(s 2))}
$$

Persamaan 1 merupakan persamaan untuk menghitung nilai kemriipan kata menggunakan metode Wu Palmer. Di mana Depth sl merupakan kedalaman dari kata ke pertama dalam wordnet (leksikal database) yang berisi banyak dataset atau disebut ontology, depth s2 juga begitu. Score yang dihasilkan dalam rentang nilai 0 sampai $1\left(0 \leq \operatorname{sim}_{\text {wup }} \leq 1\right)$. Wu palmer ini memiliki kinerja dengan proses perhitungan mencari jalur terpendek dari setiap concept, kemudian setiap jalur yang terbentuk digabungkan untuk mencari LCS-nya. Pencarian LCS (Lowest Common Subsumer) dengan cara mencari sense yang sering muncul dari dua jalur yang dihubungkan [2]. Wu palmer akan mencari kata dengan makna semantic yang terkait baik dari segi sinonim, hipernim dan akronimnya [12]. Berikut hasil matriks nilai kemiripan kata dari dua contoh kalimat di atas menggunakan metode $w u$ palmer. Gambar 2 merupakan matriks nilai perbandingan kemiripan antar kata menggunakan pendekatan wu palmer.

\begin{tabular}{|c|c|c|c|c|c|c|c|c|c|c|}
\hline & $\begin{array}{l}\text { the } \\
\text { /DT }\end{array}$ & \begin{tabular}{|l|} 
adviser \\
/NN
\end{tabular} & \begin{tabular}{|l|} 
accepted \\
/VBD
\end{tabular} & \begin{tabular}{|l} 
an \\
/DT
\end{tabular} & \begin{tabular}{|l|} 
invitation \\
/NN
\end{tabular} & $\begin{array}{l}\text { to } \\
\text { /TO }\end{array}$ & $\begin{array}{l}\text { fill } \\
\text { /VB }\end{array}$ & \begin{tabular}{|l|}
$\mathbf{a}$ \\
/DT
\end{tabular} & \begin{tabular}{|l|} 
business \\
/NN
\end{tabular} & $\begin{array}{l}\text { seminar } \\
\text { /NN }\end{array}$ \\
\hline the/DT & & & & & & & & & & - \\
\hline orator/NN & & 0.6957 & & & 0.4348 & & & & 0.2667 & 0.2222 \\
\hline found/VBD & & & 0.6667 & & & & 0.5714 & & & - \\
\hline an/DT & & -1 & & & - & & -1 & & & - \\
\hline invitation/NN & & 0.4545 & - & & $\underline{1.0000}$ & & - & - & $\underline{0.7059}$ & $\underline{0.6316}$ \\
\hline to/TO & & & & & & & - & - & & 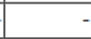 \\
\hline fill/VB & & & 0.4000 & & & & 1.0000 & & & 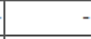 \\
\hline$a / D T$ & & & & & & & & & & - \\
\hline business/NN & & 0.2857 & & & $\underline{0.7059}$ & & - & & 1.0000 & $\underline{0.7778}$ \\
\hline seminar/NN & & $\underline{0.2353}$ & & & $\underline{0.6316}$ & & - & & $\underline{0.7778}$ & 1.0000 \\
\hline
\end{tabular}

Gambar 2. Nilai kemiripan kata (metode wu palmer)

\section{Metode Lin}

Berdasarkan pada pendekatan ini, kemiripan antar dua kata dihitung berdasarkan rumus informasi. Pendekatan lin terdiri dari normalisasi dengan kombinasi konten informasi yang membandingkan maknanya. Ukuran kesamaan pada pendekatan lin berdasarkan tiga asumsi. Pertama, dua makna yang lebih mirip adalah yang semakin banyak makna maka akan semakin memiliki kesamaan. Kedua, semakin dua makna yang sama maka semakin 
sedikit kemiripannya. Ketiga, kesamaan maksimum terjadi ketika dua makna yang identik [13]. Pendekatan lin dapat dihitung sebagai berikut [14]:

$$
\operatorname{Sim}_{\operatorname{lin}}\left(X_{1}, X_{2}\right)=\frac{2 \times \log P(C)}{\log P(C 1)+\log P(C 2)}
$$

Persamaan (2) merupakan persamaan untuk menghitung nilai kemriipan kata menggunakan metode Lin. Di mana $\mathrm{C}$ adalah kelas paling spesifik yang menggolongkan konsep $\mathrm{C} 1$, dan $\mathrm{C} 2$ adalah induk umum dari dua konsep dengan jarak simpul minimum. $\log \mathrm{P}(\mathrm{C}), \log \mathrm{P}(\mathrm{C} 1)$ dan $\log \mathrm{P}(\mathrm{C} 2)$ adalah $\log$ kemungkinan terjadinya konsep $\mathrm{C}, \mathrm{C} 1 \mathrm{dan}$ C2. Berikut hasil matriks nilai kemiripan kata dari dua contoh kalimat di atas menggunakan metode lin:

\begin{tabular}{|c|c|c|c|c|c|c|c|c|c|c|}
\hline & $\begin{array}{l}\text { the } \\
\text { /DT }\end{array}$ & \begin{tabular}{|l|} 
adviser \\
/NN
\end{tabular} & $\begin{array}{l}\text { accepted } \\
\text { /VBD }\end{array}$ & \begin{tabular}{|l} 
an \\
/DT
\end{tabular} & $\begin{array}{l}\text { invitation } \\
/ \mathrm{NN}\end{array}$ & $\begin{array}{l}\text { to } \\
\text { /TO }\end{array}$ & $\begin{array}{l}\text { fill } \\
/ \mathrm{VB}\end{array}$ & $\begin{array}{l}\mathrm{a} \\
/ \mathrm{DT}\end{array}$ & $\begin{array}{l}\text { business } \\
\text { /NN }\end{array}$ & $\begin{array}{l}\text { seminar } \\
\text { /NN }\end{array}$ \\
\hline \multicolumn{11}{|l|}{ the/DT } \\
\hline orator/NN & & 0.1862 & & 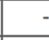 & $\underline{0.1290}$ & & & & $\underline{0.0000}$ & $\underline{0.0000}$ \\
\hline found/VBD & - & & 0.6357 & 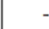 & - & & 0.3992 & & - & - \\
\hline an/DT & - & & - & - & - & 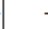 & - & & - & - \\
\hline invitation/NN & & $\underline{0.1403}$ & - & - & $\underline{1.0000}$ & & - & & $\underline{0.3261}$ & $\underline{0.0000}$ \\
\hline \multicolumn{11}{|l|}{ to/TO } \\
\hline fill/VB & - & - & 0.0000 & 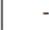 & - & & 1.0000 & & & - \\
\hline \multicolumn{11}{|l|}{ a/DT } \\
\hline business/NN & & 0.0000 & - & - & $\underline{0.3261}$ & & - & & 1.0000 & $\underline{0.0000}$ \\
\hline seminar/NN & & 0.0000 & 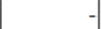 & . & 0.0000 & & - & & 0.0000 & 0.0000 \\
\hline
\end{tabular}

Gambar 3. Nilai kemiripan kata (metode lin)

Gambar 3 merupakan matriks nilai perbandingan kemiripan antar kata menggunakan pendekatan lin.

\section{Metode Path}

Pendekatan ini adalah varian dari metode distance dan pada prinsipnya dirancang untuk bekerja dengan struktur hierarki. Pendekatan shortest path dapat dihitung dengan persamaan sebagai berikut [15] :

$$
\operatorname{Sim}(C 1, C 2)=2 \times \operatorname{Max}(C 1, C 2)-S P
$$

Persamaan 3 merupakan persamaan untuk menghitung nilai kemriipan kata menggunakan metode Path. Di mana Max adalah panjang jalur maksimum di antara $\mathrm{C} 1$ dan $\mathrm{C} 2$ dalam taksonomi dan SP adalah jalur pendek menghubungkan (jumlah minimum tautan) konsep C1 ke konsep C2. Berikut hasil matriks nilai kemiripan kata dari dua contoh

\begin{tabular}{|c|c|c|c|c|c|c|c|c|c|c|}
\hline & $\begin{array}{l}\text { the } \\
\text { /DT }\end{array}$ & $\begin{array}{l}\text { adviser } \\
\text { /NN }\end{array}$ & $\begin{array}{l}\text { accepted } \\
\text { /VBD }\end{array}$ & \begin{tabular}{|l|} 
an \\
$/ D T$
\end{tabular} & $\begin{array}{l}\text { invitation } \\
/ \mathrm{NN}\end{array}$ & $\begin{array}{l}\text { to } \\
\text { /To }\end{array}$ & $\begin{array}{l}\text { fill } \\
/ \mathrm{VB}\end{array}$ & \begin{tabular}{|l}
$\mathbf{a}$ \\
$/ \mathrm{DT} T$
\end{tabular} & \begin{tabular}{|l} 
business \\
/NN
\end{tabular} & $\begin{array}{l}\text { seminar } \\
\text { /NN }\end{array}$ \\
\hline \multicolumn{11}{|l|}{ the/DT } \\
\hline orator/NN & & 0.1250 & - & 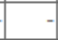 & 0.0714 & 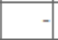 & - & 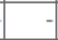 & 0.0833 & 0.0667 \\
\hline found/VBD & - & & 0.3333 & & - & & 0.2500 & & t & - \\
\hline \multicolumn{11}{|l|}{ an/DT } \\
\hline invitation/NN & & $\underline{0.0769}$ & - & & $\underline{1.0000}$ & 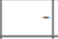 & - & 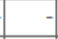 & $\underline{0.1667}$ & $\underline{0.1250}$ \\
\hline \multicolumn{11}{|l|}{ to/To } \\
\hline fill/VB & 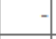 & & $\underline{0.2500}$ & & - & & 1.0000 & & 1 & - \\
\hline \multicolumn{11}{|l|}{ a/DT } \\
\hline business/NN & & $\underline{0.0909}$ & -1 & & $\underline{0.1667}$ & 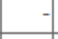 & - & & $\underline{1.0000}$ & 0.2000 \\
\hline seminar/NN & & $\underline{0.0714}$ & - & & $\underline{0.1250}$ & 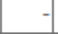 & t & & $\underline{0.2000}$ & 1.0000 \\
\hline
\end{tabular}
kalimat di atas menggunakan metode path:

Gambar 4. Nilai kemiripan kata (metode path) 
Gambar 4 merupakan matriks nilai perbandingan kemiripan antar kata menggunakan pendekatan path.

\section{Pembobotan Kalimat Menggunakan AHP}

Pembobotan kalimat dimulai dengan menentukan nilai bobot prioritas dari masingmasing kriteria dengan menggunakan AHP. Nilai bobot ini digunakan untuk proses pembobotan nilai kemiripan kata yang kemudian digunakan untuk perhitungan nilai kemiripan kalimat. AHP (Analytical Hierarchy Process) adalah salah satu sistem yang paling inklusif dianggap dapat mengambil keputusan dengan beberapa kriteria karena metode ini dilakukan untuk merumuskan masalah secara hierarki dan kriteria yang ditentukan berupa bentuk kuantitatif ataupun kualitatif [16]. Perhitungan bobot nilai dengan AHP dapat dihitung menggunakan AHP Calculator. Dari priority vector yang diperoleh akan digunakan sebagai pembobotan kriteria verb, dan noun yang digunakan untuk perhitungan kemiripan kalimat. Pemilihan kriteria AHP yaitu verb, dan noun dikarenakan dalam perhitungan nilai kemiripan pada WS4J hanya kelas verb, dan noun yang terhitung nilai kemiripannya sedangkan kelas yang lain diabaikan. Berikut hasil perhitungan AHP menggunakan AHP Calculator :

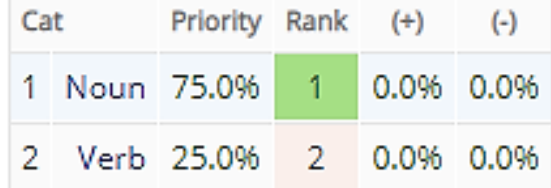

Gambar 5. Bobot Kriteria Uji 1

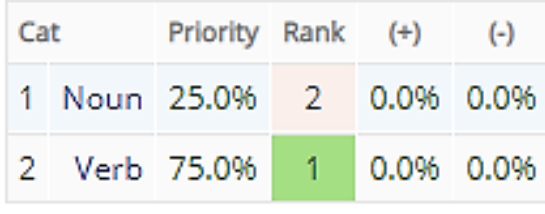

Gambar 6. Bobot Kriteria Uji 2

Dalam perhitungan nilai bobot prioritas pada penelitian ini terdapat dua uji coba. Gambar 5 merupakan uji coba yang pertama yaitu noun memiliki nilai lebih prioritas dari verb. Gambar 6 merupakan uji coba yang kedua yaitu verb lebih prioritas dari noun. Nilai bobot prioritasnya sebesar $75 \%$ atau 0.75 dan $25 \%$ atau 0.25 .

\section{Contextual Similarity between Sentence}

Contextual similarity merupakan pengukuran tingkat kemiripan semantic berdasarkan makna katanya. Pada perhitungan contextual similarity menggunakan algoritma $w u$ palmer, lin, dan path untuk menghitung kemiripan antar kata pada kalimat [3][8][9]. Untuk menghitung nilai kemiripan makna antar kalimatnya yaitu dengan menghitung pembobotan matriks nilai kemiripan kata. Sebelum dilakukan perhitungan pembobotan yakni dilakukan proses normalisasi matriks nilai kemiripan kata dengan cara menghitung rata-rata jumlah nilai tertinggi dari tiap kolom pada masing-masing jenis kata. Setelah dilakukan normalisasi, kemudian dilakukan perhitungan pembobotan nilai kemiripan kata sehingga didapatkan persamaan untuk menghitung sentence similarity berdasarkan contextual-nya sebagai berikut:

$$
\text { Sentence Similarity }=\left(\overline{n_{\max }} x b_{n}\right)+\left(\overline{v_{\max }} x b_{v}\right)
$$

Persamaan 4 menunjukkan persamaan untuk menghitung nilai kemiripan kalimat yang mana merupakan hasil pembobotan kemiripan kata dengan mengakumulasikan matriks nilai perbandingan kata dengan nilai bobot kelas kata. Di mana $\overline{n_{\max }}$ merupakan rata-rata dari jumlah nilai tertinggi tiap kolom matriks kemiripan kata dengan kriteria Noun. $\overline{v_{\max }}$ rata-rata dari jumlah nilai tertinggi tiap kolom matriks kemiripan kata dengan kriteria Verb. 
Sedangkan untuk $b_{n}$ dan $b_{v}$ merupakan bobot nilai dari kriteria Noun dan Verb yang telah dihitung menggunakan AHP. Di bawah ini merupakan contoh perhitungan nilai sentence similarity dari dua contoh kalimat di atas :

\begin{tabular}{|c|c|c|c|c|c|c|c|c|c|c|}
\hline & $\begin{array}{l}\text { the } \\
\text { /DT }\end{array}$ & \begin{tabular}{|l|}
$\begin{array}{l}\text { adviser } \\
\text { /NN }\end{array}$ \\
\end{tabular} & \begin{tabular}{|l|} 
accepted \\
/VBD
\end{tabular} & \begin{tabular}{l|l|} 
an \\
/DT
\end{tabular} & \begin{tabular}{|l|} 
invitation \\
/NN
\end{tabular} & \begin{tabular}{|l|l|} 
to \\
/ To
\end{tabular} & \begin{tabular}{|l|l} 
fill \\
$/ \mathrm{VB}$ \\
\end{tabular} & \begin{tabular}{|l|}
$\mathrm{a}$ \\
/DT \\
\end{tabular} & \begin{tabular}{|l|} 
business \\
/NN
\end{tabular} & $\begin{array}{l}\text { seminar } \\
\text { /NN }\end{array}$ \\
\hline \multicolumn{11}{|l|}{ the/DT } \\
\hline orator/NN & & 0.6957 & & & 0.4348 & - & 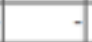 & & 0.2667 & 0.2222 \\
\hline found/VBD & & & 0.6667 & & 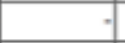 & & 0.5714 & & & \\
\hline \multicolumn{11}{|l|}{ an/DT } \\
\hline invitation/NN & & 0.4545 & - & & 1.0000 & - & - & & 0.7059 & $\underline{0.6316}$ \\
\hline to/To & & & & & - & 7 & - & & -1 & $=$ \\
\hline fill/VB & & & 0.4000 & & & & 1.0000 & & $\Rightarrow$ & . \\
\hline \multicolumn{11}{|l|}{ a/DT } \\
\hline business/NN & & 0.2857 & & & 0.7059 & - & - & & 1.0000 & 0.7778 \\
\hline seminar/NN & & 0.2353 & - & 7 & 0.6316 & $\theta$ & - & & 0.7778 & 1.0000 \\
\hline Nilai Max & & 0.6957 & 0.6667 & & 1 & & 1 & & 1 & 1 \\
\hline
\end{tabular}

Gambar 7. Matriks nilai kemiripan kata (proses normalisasi)

Gambar 7 merupakan proses normalisasi matriks perbandingan kemiripan kata, kemudian dihitung menggunakan persamaan kemiripan kalimat. Berikut merupakan proses perhitungannya :

$\sum n=0.6957+1+1+1=3.6957$

$\bar{n}=\frac{3.6957}{4}=0.923925$

$\Sigma v=0.6667+1=1.6667$

$\bar{n}=\frac{1.6667}{2}=0.83335$

$\operatorname{Sim}(\mathbf{0 . 7 5}, \mathbf{0 . 2 5})=$ Sentence Similarity $=(\bar{n} \times 0.75)+(\bar{v} \times 0.25)$

$\operatorname{Sim}(\mathbf{0 . 7 5}, \mathbf{0 . 2 5})=(0.923925 \times 0.75)+(0.83335 \times 0.25)$

$\operatorname{Sim}(0.75,0.25)=0.901281$

$\operatorname{Sim}(0.25,0.75)=$ Sentence Similarity $=(\bar{n} x 0.25)+(\bar{v} x 0.75)$

$\operatorname{Sim}(0.25,0.75)=(0.923925 \times 0.25)+(0.83335 \times 0.75)$

$\operatorname{Sim}(0.25,0.75)=0.855994$

Perhitungan di atas menunjukkan bahwa $\Sigma^{n}$ perhitungan jumlah nilai noun, dan $\Sigma^{v}$ merupakan perhitungan jumlah dari nilai verb. $\bar{n}$ merupakan nilai rata-rata dari jumlah noun, dan $\bar{v}$ merupakan nilai rata-rata dari jumlah verb. $\operatorname{Sim}(0.75,0.25)$ merupakan perhitungan nilai kemiripan dengan formula uji yang pertama, dan $\operatorname{Sim}(0.25,0.75)$ merupakan perhitungan nilai kemiripan dengan formula uji yang kedua.

\section{PEMBAHASAN}

\section{Menghitung Word Similarity}

Perhitungan kemiripan antar kata dilakukan dengan pendekatan wu palmer, lin, dan path menggunakan WS4J. Skenario pengujian yang dilakukan yaitu dengan melibatkan tiga kriteria tingkat kemiripan kalimat yaitu mirip, sedang, dan tidak mirip. Berikut adalah hasil perhitungannya:

Contoh kalimat :

- Sentence $1:$ the speaker received an invitation to fill a business seminar

- Sentence 2 : the talker got an invitation to fill a business seminar 
- Sentence 3 : the advisor accept invitations to attend business seminars

- Sentence 4: The entrepreneur was asked to convey motivation to participants

Dari keempat contoh kalimat tersebut kemudian dikategorikan perbandingan antar kalimat sesuai dengan tingkat kemiripannya sebagai berikut :

a. Dua kalimat yang mirip

- Sentence $1:$ The speaker received an invitation to fill a business seminar

- Sentence 2 : The talker got an invitation to fill a business seminar

\begin{tabular}{|c|c|c|c|c|c|c|c|c|c|c|}
\hline & \begin{tabular}{|l|} 
the \\
/DT
\end{tabular} & \begin{tabular}{|l|} 
speaker \\
/NN
\end{tabular} & \begin{tabular}{|l|} 
received \\
/VBD
\end{tabular} & \begin{tabular}{|l|} 
an \\
/DT
\end{tabular} & \begin{tabular}{|l|} 
invitation \\
/NN
\end{tabular} & $\begin{array}{l}\text { to } \\
\text { /To }\end{array}$ & $\begin{array}{l}\text { fill } \\
\text { /VB }\end{array}$ & $\begin{array}{l}\mathrm{a} \\
\text { /DT }\end{array}$ & \begin{tabular}{|l|} 
business \\
/NN
\end{tabular} & $\begin{array}{l}\text { seminar } \\
\text { /NN }\end{array}$ \\
\hline \multicolumn{11}{|l|}{ the/DT } \\
\hline talker/NN & & 1.0000 & & & 0.4545 & & & & 0.2857 & 0.2353 \\
\hline got/VBD & & & 1.0000 & & - & & 0.7500 & & & \\
\hline \multicolumn{11}{|l|}{ an/DT } \\
\hline invitation/NN & & 0.5217 & & & 1.0000 & & & & 0.7059 & 0.6316 \\
\hline \multicolumn{11}{|l|}{ to/To } \\
\hline fill/VB & & & 0.5714 & & - & & 1.0000 & & & \\
\hline \multicolumn{11}{|l|}{ a/DT } \\
\hline business/NN & & 0.2857 & & & 0.7059 & & & & 1.0000 & 0.7778 \\
\hline seminar/NN & & 0.2353 & & & 0.6316 & & & & 0.7778 & 1.0000 \\
\hline
\end{tabular}

Gambar 8. Matriks nilai kemiripan wu palmer(sentence1 - sentence 2)

\begin{tabular}{|c|c|c|c|c|c|c|c|c|c|c|}
\hline & \begin{tabular}{|l} 
the \\
/DT
\end{tabular} & $\begin{array}{l}\text { speaker } \\
\text { /NN }\end{array}$ & \begin{tabular}{|l|} 
received \\
/VBD
\end{tabular} & \begin{tabular}{|l|} 
an \\
/DT \\
\end{tabular} & \begin{tabular}{|l|} 
invitation \\
/NN
\end{tabular} & \begin{tabular}{|l|} 
to \\
/TO
\end{tabular} & $\begin{array}{l}\text { fill } \\
/ \mathrm{VB}\end{array}$ & \begin{tabular}{|l|l}
$\mathbf{a}$ \\
$/ \mathrm{DT}$ \\
\end{tabular} & \begin{tabular}{|l|} 
business \\
/NN
\end{tabular} & \begin{tabular}{|l|} 
seminar \\
/NN
\end{tabular} \\
\hline \multicolumn{11}{|l|}{ the/DT } \\
\hline talker/NN & & $\underline{1.0000}$ & & & 0.1465 & & & & 0.0000 & 0.0000 \\
\hline got/VBD & & & 1.0000 & & & & 0.6278 & & & \\
\hline \multicolumn{11}{|l|}{ an/DT } \\
\hline invitation/NN & & 0.2395 & & & 1.0000 & & & & 0.3261 & 0.0000 \\
\hline \multicolumn{11}{|l|}{ to/TO } \\
\hline fill/VB & & & 0.4150 & & & & 1.0000 & & & \\
\hline \multicolumn{11}{|l|}{$a / D T$} \\
\hline business/NN & & 0.0000 & & & 0.3261 & & & & 1.0000 & 0.0000 \\
\hline seminar/NN & & 0.0000 & & & 0.0000 & & & & 0.0000 & 0.0000 \\
\hline
\end{tabular}

Gambar 9. Matriks nilai kemiripan lin(sentence1 - sentence 2)

\begin{tabular}{|c|c|c|c|c|c|c|c|c|c|c|}
\hline & $\begin{array}{l}\text { the } \\
\text { /DT }\end{array}$ & \begin{tabular}{|l|} 
speaker \\
/NN
\end{tabular} & \begin{tabular}{|l|} 
received \\
/VBD
\end{tabular} & \begin{tabular}{|l} 
an \\
/DT
\end{tabular} & \begin{tabular}{|l|} 
invitation \\
/NN
\end{tabular} & \begin{tabular}{|l|} 
to \\
/TO
\end{tabular} & \begin{tabular}{|l|} 
fill \\
/vB
\end{tabular} & \begin{tabular}{|l|}
$\mathbf{a}$ \\
$\mathrm{DT}$
\end{tabular} & $\begin{array}{l}\text { business } \\
\text { /NN }\end{array}$ & $\begin{array}{l}\text { seminar } \\
\text { /NN }\end{array}$ \\
\hline \multicolumn{11}{|l|}{ the/DT } \\
\hline advisors/NNS & & 0.1429 & & & 0.0769 & & & & 0.0909 & $\underline{0.0714}$ \\
\hline accept/VBP & & & 0.5000 & & & & 0.2500 & & & \\
\hline invitations/NNS & & 0.0833 & & & 1.0000 & & & & 0.1667 & $\underline{0.1250}$ \\
\hline \multicolumn{11}{|l|}{ to/TO } \\
\hline attend/VB & & & 0.2500 & & & & 0.3333 & & & \\
\hline business/NN & & 0.0909 & & & 0.1667 & & & & $\underline{1.0000}$ & 0.2000 \\
\hline seminars/NNS & & $\underline{0.0714}$ & & & 0.1250 & & & & 0.2000 & 1.000 \\
\hline
\end{tabular}

Gambar 10. Matriks nilai kemiripan path(sentence 1 - sentence 2)

Gambar 8, Gambar 9, dan Gambar 10 merupakan hasil matriks perbandingan nilai kemiripan antara sentence 1, dan sentence 2 menggunakan metode wu palmer, lin, dan path. Sentence 1 , dan sentence 2 dinyatakan sebagai dua kalimat yang mirip secara makna kalimatnya.

b. Dua kalimat yang tingkat kemiripannya "sedang"

Perbandingan pertama :

- Sentence 1 : The speaker received an invitation to fill a business seminar

- Sentence 3 : The advisor accept invitations to attend business seminar

Perbandingan kedua :

- Sentence 2 : The talker got an invitation to fill a business seminar

- Sentence 3 : The advisor accept invitations to attend business seminars 
Gambar 11, Gambar 12, dan Gambar 13 merupakan hasil matriks perbandingan nilai kemiripan antara sentence 1 , dan sentence 3 menggunakan metode wu palmer, lin, dan path. Sentence 1, dan sentence 3 merupakan perbandingan dua kalimat yang memiliki tingkat kemiripan sedang, artinya dalam sinonim kata keduanya masih memiliki kemiripan.

\begin{tabular}{|c|c|c|c|c|c|c|c|c|c|c|}
\hline & $\begin{array}{l}\text { the } \\
\text { /DT }\end{array}$ & $\begin{array}{l}\text { speaker } \\
\text { /NN }\end{array}$ & \begin{tabular}{|l|} 
received \\
/VBD
\end{tabular} & \begin{tabular}{|l|} 
an \\
/DT \\
\end{tabular} & \begin{tabular}{|l|} 
invitation \\
/NN
\end{tabular} & \begin{tabular}{|l|} 
to \\
/TO
\end{tabular} & $\begin{array}{l}\text { fill } \\
\text { /VB }\end{array}$ & \begin{tabular}{|l|}
$\mathbf{a}$ \\
$/ \mathrm{DT}$ \\
\end{tabular} & \begin{tabular}{|l|} 
business \\
/NN
\end{tabular} & $\begin{array}{l}\text { seminar } \\
/ \mathrm{NN}\end{array}$ \\
\hline \multicolumn{11}{|l|}{ the/DT } \\
\hline advisor/NN & & $\underline{0.7273}$ & & & 0.4545 & & & & 0.2857 & 0.2353 \\
\hline accept/VB & & & 0.8889 & & & & 0.4000 & & & \\
\hline invitations/NNS & & $\underline{0.5217}$ & & & $\underline{1.0000}$ & & & & 0.7059 & $\underline{0.6316}$ \\
\hline \multicolumn{11}{|l|}{ to/TO } \\
\hline attend/VB & & & 0.5714 & & & & 0.6667 & & & \\
\hline business $/ \mathrm{NN}$ & & $\underline{0.2857}$ & & & $\underline{0.7059}$ & & & & $\underline{1.0000}$ & $\underline{0.7778}$ \\
\hline seminars/NNS & & 0.2353 & & & 0.6316 & & & & 0.7778 & 1.0000 \\
\hline
\end{tabular}

Gambar 11. Matriks nilai kemiripan wu palmer(sentence1 - sentence 3)

\begin{tabular}{|c|c|c|c|c|c|c|c|c|c|c|}
\hline & $\begin{array}{l}\text { the } \\
\text { /DT }\end{array}$ & \begin{tabular}{|l|} 
speaker \\
/NN
\end{tabular} & \begin{tabular}{|l|} 
received \\
/VBD
\end{tabular} & $\begin{array}{l}\text { an } \\
\text { /DT }\end{array}$ & \begin{tabular}{|l|} 
invitation \\
/NN
\end{tabular} & \begin{tabular}{|l|l|} 
to \\
$/$ TO
\end{tabular} & $\begin{array}{l}\text { fill } \\
\text { /VB }\end{array}$ & $\begin{array}{l}\mathrm{a} \\
/ \mathrm{DT}\end{array}$ & \begin{tabular}{|l|} 
business \\
/NN
\end{tabular} & $\begin{array}{l}\text { seminar } \\
\text { /NN }\end{array}$ \\
\hline \multicolumn{11}{|l|}{ the/DT } \\
\hline advisor/NN & & 0.2125 & & & 0.1403 & & & & 0.0000 & 0.0000 \\
\hline accept/VB & & & 0.7651 & & & & 0.0000 & & & \\
\hline invitations/NNS & & 0.2395 & & & 1.0000 & & & & 0.3261 & 0.0000 \\
\hline \multicolumn{11}{|l|}{ to $/ \mathrm{TO}$} \\
\hline attend/VB & & & 0.4555 & & & & \begin{tabular}{|l|l|}
0.5307 \\
\end{tabular} & & & \\
\hline business/NN & & 0.0000 & & & 0.3261 & & & & 1.0000 & 0.0000 \\
\hline seminars/NNS & & 0.0000 & & & 0.0000 & & & & 0.0000 & 0.0000 \\
\hline
\end{tabular}

Gambar 12. Matriks nilai kemiripan lin(sentence1 - sentence 3)

\begin{tabular}{|c|c|c|c|c|c|c|c|c|c|c|}
\hline & \begin{tabular}{|l|} 
the \\
/DT
\end{tabular} & \begin{tabular}{|l|} 
speaker \\
/NN
\end{tabular} & \begin{tabular}{|l|} 
received \\
/VBD
\end{tabular} & $\begin{array}{l}\text { an } \\
\text { /DT }\end{array}$ & \begin{tabular}{|l|} 
invitation \\
$/ \mathrm{NN}$
\end{tabular} & \begin{tabular}{|l|} 
to \\
/TO
\end{tabular} & $\begin{array}{l}\text { fill } \\
\text { /VB }\end{array}$ & \begin{tabular}{|l|}
$a$ \\
$D T$
\end{tabular} & \begin{tabular}{|l|} 
business \\
/NN
\end{tabular} & \begin{tabular}{|l|} 
seminar \\
/NN
\end{tabular} \\
\hline \multicolumn{11}{|l|}{ the/DT } \\
\hline advisor/NN & & 0.1429 & & & 0.0769 & & & & 0.0909 & 0.0714 \\
\hline accept/VB & & & 0.5000 & & & & 0.2500 & & & \\
\hline invitations/NNS & & 0.0833 & & & 1.0000 & & & & 0.1667 & 0.1250 \\
\hline \multicolumn{11}{|l|}{ to/TO } \\
\hline attend/VB & & & 0.2500 & & & & 0.3333 & & & \\
\hline business/NN & & 0.0909 & & & 0.1667 & & & & $\underline{1.0000}$ & 0.200 \\
\hline seminars/NNS & & 0.0714 & & & 0.1250 & & & & 0.2000 & 1.000 \\
\hline
\end{tabular}

Gambar 13. Matriks nilai kemiripan path(sentencel - sentence 3)

c. Dua kalimat yang tidak mirip

Perbandingan pertama :

- Sentence 1: The speaker received an invitation to fill a business seminar

- Sentence 4 : The entrepreneur was asked to convey motivation to participants in the entrepreneurship seminar

Perbandingan kedua :

- Sentence 2 : The talker got an invitation to fill a business seminar

- Sentence 4 : The entrepreneur was asked to convey motivation to participants in the entrepreneurship seminar

Perbandingan ketiga :

- Sentence 3 : The advisor accept invitations to attend business seminars

- Sentence 4: The entrepreneur was asked to convey motivation to participants in the entrepreneurship seminar 


\begin{tabular}{|c|c|c|c|c|c|c|c|c|c|c|}
\hline & \begin{tabular}{|l|} 
the \\
/DT
\end{tabular} & \begin{tabular}{|l|} 
speaker \\
/NN
\end{tabular} & \begin{tabular}{|l|} 
received \\
/VBD
\end{tabular} & \begin{tabular}{|l} 
an \\
/DT
\end{tabular} & \begin{tabular}{|l|} 
invitation \\
/NN
\end{tabular} & \begin{tabular}{|l|} 
to \\
/To
\end{tabular} & \begin{tabular}{|l} 
fill \\
/VB
\end{tabular} & \begin{tabular}{|l|}
$\mathbf{a}$ \\
$/ \mathrm{DT}$ \\
\end{tabular} & $\begin{array}{l}\text { business } \\
\text { /NN }\end{array}$ & $\begin{array}{l}\text { seminar } \\
\text { /NN }\end{array}$ \\
\hline The/DT & & & & & & - & - & & & \\
\hline entrepreneur/NN & & 0.7273 & & & 0.4545 & & & & 0.2857 & 0.2353 \\
\hline was/VBD & & & $\underline{0.5000}$ & & - & & 0.8000 & & & \\
\hline asked/VBN & & & 0.5000 & & 4 & & 0.4000 & & & \\
\hline to/TO & & - & & & - & & & & & 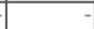 \\
\hline convey/VB & & & 0.4000 & & & & 0.5000 & & & \\
\hline motivation/NN & & 0.3077 & & & $\underline{0.7500}$ & & & & 0.8000 & 0.7059 \\
\hline to/TO & & & & & & & & & & \\
\hline participants/NNS & & 0.7619 & & & $\underline{0.4762}$ & & & & 0.3077 & 0.2500 \\
\hline in/IN & & - & & & - & & & & & - \\
\hline the/DT & & -1 & & & -1 & & & & -7 & - \\
\hline entrepreneurship/NN & & -1 & & & -1 & & & & -1 & -1 \\
\hline seminar/NN & & 0.2353 & & & 0.6316 & & & & 0.7778 & 1.0000 \\
\hline
\end{tabular}

Gambar 14. Matriks nilai kemiripan wu palmer(sentence1 - sentence 4)

\begin{tabular}{|c|c|c|c|c|c|c|c|c|c|c|}
\hline & $\begin{array}{l}\text { the } \\
\text { /DT }\end{array}$ & \begin{tabular}{|l|} 
speaker \\
/NN
\end{tabular} & \begin{tabular}{|l|} 
received \\
/VBD
\end{tabular} & \begin{tabular}{|l|} 
an \\
/DT
\end{tabular} & \begin{tabular}{|l|} 
invitation \\
/NN
\end{tabular} & $\begin{array}{l}\text { to } \\
\text { /To }\end{array}$ & \begin{tabular}{|l} 
fill \\
/VB
\end{tabular} & $\begin{array}{l}\mathbf{a} \\
/ \mathrm{DT}\end{array}$ & \begin{tabular}{|l|} 
business \\
/NN
\end{tabular} & \begin{tabular}{|l|} 
seminar \\
/NN
\end{tabular} \\
\hline The/DT & & & & & & & & & & \\
\hline entrepreneur/NN & & 0.2055 & & & 0.1361 & & & & 0.0000 & 0.0000 \\
\hline was/VBD & & & $\underline{0.0000}$ & & & & 0.6411 & & - & \\
\hline asked/VBN & & - & 0.0000 & & -1 & & 0.0000 & & & \\
\hline to $/ \mathrm{TO}$ & & - & - & - & -1 & & 4 & & & \\
\hline convey/VB & & - & 0.0000 & 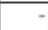 & & & 0.0000 & & & \\
\hline motivation/NN & & 0.0000 & & & 0.2126 & & & & 0.2869 & 0.0000 \\
\hline to $/ \mathrm{TO}$ & & & & & & & & & & \\
\hline participants/NNS & & $\underline{0.2472}$ & & & 0.1610 & & & & $\underline{0.0000}$ & 0.0000 \\
\hline in/IN & & - & & & -1 & & & & & \\
\hline the/DT & & & & & -1 & & & & - & - \\
\hline entrepreneurship/NN & & -1 & & & -1 & & & & -1 & -1 \\
\hline seminar/NN & & 0.0000 & & & 0.0000 & & & & 0.0000 & 0.0000 \\
\hline
\end{tabular}

Gambar 15. Matriks nilai kemiripan lin(sentence1 - sentence 4)

\begin{tabular}{|c|c|c|c|c|c|c|c|c|c|c|}
\hline & \begin{tabular}{|l|} 
the \\
/DT
\end{tabular} & \begin{tabular}{|l|} 
speaker \\
/NN
\end{tabular} & \begin{tabular}{|l|} 
received \\
/VBD
\end{tabular} & \begin{tabular}{|l|} 
an \\
/DT \\
\end{tabular} & \begin{tabular}{|l|} 
invitation \\
/NN
\end{tabular} & \begin{tabular}{|l|} 
to \\
/TO
\end{tabular} & $\begin{array}{l}\text { fill } \\
\text { /VB }\end{array}$ & \begin{tabular}{|l|}
$\mathbf{a}$ \\
/DT \\
\end{tabular} & \begin{tabular}{|l|} 
business \\
/NN
\end{tabular} & \begin{tabular}{|l|} 
seminar \\
/NN
\end{tabular} \\
\hline The/DT & & & & - & & & - & - & & \\
\hline entrepreneur/NN & & 0.1429 & & & 0.0769 & & & & 0.0909 & 0.0714 \\
\hline was/VBD & & & 0.3333 & & & & 0.5000 & & & \\
\hline asked/VBN & & & 0.3333 & & & & 0.2500 & & & \\
\hline to/TO & & & & & & & & & & \\
\hline convey/VB & & & 0.2500 & & & & 0.2000 & & & \\
\hline motivation/NN & & 0.1000 & -1 & & 0.2000 & & - & & 0.2500 & 0.1667 \\
\hline to $/ \mathrm{TO}$ & & & & & & & & & & \\
\hline participants/NNS & & 0.1667 & - & & 0.0833 & & - & & $\underline{0.1000}$ & $\underline{0.0769}$ \\
\hline in/IN & & & - & & & & - & & & - \\
\hline the/DT & & & , & & & & - & & & - \\
\hline entrepreneurship/NN & & -1 & - & & $\underline{-1}$ & & -1 & & -1 & -1. \\
\hline seminar/NN & & 0.0714 & 7 & & 0.1250 & & & & 0.2000 & 1.0000 \\
\hline
\end{tabular}

Gambar 16. Matriks nilai kemiripan path(sentence 1 - sentence 4)

Gambar 14, Gambar 15, dan Gambar 16 merupakan hasil matriks perbandingan nilai kemiripan antara sentence 1, dan sentence 4 menggunakan metode wu palmer, lin, dan path. Sentence 1 , dan sentence 4 merupakan perbandingan dua kalimat yang tidak memiliki kemiripan, artinya dalam sinonim kata keduanya tidak memiliki kemiripan kata.

\section{Menghitung Sentence Similarity}

Setelah diperoleh nilai kemiripan kata dari keempat contoh kalimat di atas, kemudian dilakukan perhitungan sentence similarity. Berikut ini merupakan hasil perhitungan kemiripan kalimat dengan menggunakan dua jenis bobot nilai yaitu $(0.75,0.25)$, dan $(0.25$, $0.75)$ :

Tabel 2. Hasil perhitungan sentence similarity

\begin{tabular}{|c|c|c|c|c|c|c|}
\hline Method & $\sum n$ & $\Sigma v$ & $\bar{n}$ & $\bar{v}$ & $\operatorname{Sim}(\mathbf{0 . 7 5}, \mathbf{0 . 2 5})$ & $\operatorname{Sim}(\mathbf{0 . 2 5}, \mathbf{0 . 7 5})$ \\
\hline $\begin{array}{c}\text { WuP } \\
\left(S_{1}-S_{2}\right)\end{array}$ & 4 & 2 & 1 & 1 & 1 & 1 \\
\hline $\operatorname{Lin}\left(S_{1}-S_{2}\right)$ & 4 & 2 & 1 & 1 & 1 & 1 \\
\hline
\end{tabular}




\begin{tabular}{|c|c|c|c|c|c|c|}
\hline $\begin{array}{c}\text { Path } \\
\left(S_{1}-S_{2}\right)\end{array}$ & 4 & 2 & 1 & 1 & 1 & 1 \\
\hline $\begin{array}{c}\text { WuP } \\
\left(S_{1}-S_{3}\right)\end{array}$ & 3.7273 & 1.8889 & 0.931825 & 0.94445 & 0.934981 & 0.941294 \\
\hline Lin $\left(S_{1}-S_{3}\right)$ & 2.2395 & 1.7651 & 0.559875 & 0.88255 & 0.640544 & 0.801881 \\
\hline $\begin{array}{c}\text { Path } \\
\left(S_{1}-S_{3}\right)\end{array}$ & 3.1429 & 1.5 & 0.785725 & 0.75 & 0.776794 & 0.758931 \\
\hline $\begin{array}{c}\text { WuP } \\
\left(S_{1}-S_{4}\right)\end{array}$ & 3.9565 & 2 & 0.989125 & 1 & 0.991844 & 0.997281 \\
\hline Lin $\left(S_{1}-S_{4}\right)$ & 2.8713 & 2 & 0.717825 & 1 & 0.788369 & 0.929456 \\
\hline $\begin{array}{c}\text { Path } \\
\left(S_{1}-S_{4}\right)\end{array}$ & 3.5 & 2 & 0.875 & 1 & 0.90625 & 0.96875 \\
\hline $\begin{array}{c}\text { WuP } \\
\left(S_{2}-S_{3}\right)\end{array}$ & 3.7273 & 1.8 & 0.931825 & 0.9 & 0.923869 & 0.907956 \\
\hline $\mathbf{L i n}\left(S_{2}-S_{3}\right)$ & 2.2125 & 1.7712 & 0.553125 & 0.8856 & 0.636244 & 0.802481 \\
\hline $\begin{array}{c}\text { Path } \\
\left(S_{2}-S_{3}\right)\end{array}$ & 3.1429 & 1.5 & 0.785725 & 0.75 & 0.776794 & 0.758931 \\
\hline $\begin{array}{c}\text { WuP } \\
\left(S_{2}-S_{4}\right)\end{array}$ & 3.9565 & 2 & 0.989125 & 1 & 0.991844 & 0.997281 \\
\hline Lin $\left(S_{2}-S_{4}\right)$ & 2.8713 & 2 & 0.717825 & 1 & 0.788369 & 0.929456 \\
\hline $\begin{array}{c}\text { Path } \\
\left(S_{2}-S_{4}\right)\end{array}$ & 3.5 & 2 & 0.875 & 1 & 0.90625 & 0.96875 \\
\hline $\begin{array}{c}\text { WuP } \\
\left(S_{3}-S_{4}\right)\end{array}$ & 3.6957 & 1.6667 & 0.923925 & 0.83335 & 0.901281 & 0.855994 \\
\hline Lin $\left(S_{3}-S_{4}\right)$ & 2.1862 & 1.6357 & 0.54655 & 0.81785 & 0.614375 & 0.750025 \\
\hline $\begin{array}{c}\text { Path } \\
\left(S_{3}-S_{4}\right)\end{array}$ & 3.125 & 1.3333 & 0.78125 & 0.66665 & 0.7526 & 0.6953 \\
\hline
\end{tabular}

Pada Tabel 2 menunjukkan bahwa hasil nilai kemiripan kalimat pada $\left(\boldsymbol{S}_{\mathbf{1}}-\boldsymbol{S}_{2}\right)$ yaitu bernilai 1 berarti makna kedua kalimat tersebut adalah sama. Perhitungan kemiripan kalimat dengan formula $\operatorname{Sim}(\mathbf{0 . 7 5}, \mathbf{0 . 2 5})$ pada hasil percobaan di atas menghasilkan 5 nilai yang lebih tinggi, sedangkan perhitungan dengan formula $\operatorname{Sim}(\mathbf{0 . 2 5}, \mathbf{0 . 7 5})$ menghasilkan 10 nilai yang lebih tinggi. Hal ini menunjukkan bahwa formula $\operatorname{Sim}(\mathbf{0 . 2 5}, \mathbf{0 . 7 5})$ memiliki 5 nilai yang lebih besar dibandingkan dengan formula $\operatorname{Sim}(\mathbf{0 . 7 5}, \mathbf{0 . 2 5})$, sehingga hasil uji coba menunjukkan bahwa nilai bobot prioritas noun sebesar 0.25 dan verb bernilai 0.75 .

\section{KESIMPULAN}

Berdasarkan penelitian yang telah dilakukan dapat disimpulkan bahwa jenis kriteria yang digunakan untuk pembobotan kalimat dalam menentukan nilai sentence similarity yaitu noun dan verb dengan bobot masing-masing adalah 0.25 dan 0.75 . Dari nilai bobot prioritas antara noun dan verb dikalkulasikan bersama matriks nilai word similarity yang dihitung menggunakan WS4J sehingga diperoleh formula untuk menghitung nilai sentence similarity yaitu $\left(\overline{n_{\max }} x b_{n}\right)+\left(\overline{v_{\max }} x b_{v}\right) \cdot \overline{n_{\max }}$ merupakan rata-rata dari jumlah nilai tertinggi tiap kolom matriks kemiripan kata dengan kriteria noun. Sedangkan $\overline{v_{\max }}$ merupakan rata-rata dari jumlah nilai tertinggi tiap kolom matriks kemiripan kata dengan kriteria verb. Nilai $b_{n}$ adalah 0.25 dan nilai $b_{v}$ adalah 0.75 . 


\section{REFERENSI}

[1] Z. Wang, H. Mi and A. Ittycheriah, "Sentence Similarity Learning by Lexical Decomposition and Composition," Proceedings of COLING 2016, the 26th International Conference on Computational Linguistics: Technical Papers, pp. 1340-1349, 2016.

[2] A. Maulana, M. Bijaksana Arif and M. Syahrul Mubarok, "Perancangan Semantic Similarity based on Word Thesaurus Menggunakan Pengukuran Omiotis Untuk Pencarian Aplikasi pada I-

GRACIAS," e-Proceeding of Engineering, vol. 3, no. 2, p. 3689, 2016.

[3] Z. Wang, H. Mi and A. Ittycheriah, "Sentence Similarity Learning by Lexical Decomposition and Composition," 2017.

[4] Y. Li, D. McLean, Z. A. Bandar, J. D, O'shea and K. Crockett, "Sentence Similarity Based on Semantic Nets," IEEE Transactions On Knowledge And Data Engineering, vol. 18, no. 8, pp. 11381150, 2006.

[5] K. O'Shea, "An approach to conversational agent design using semantic," Appl Intell, p. 558-568, 2012.

[6] L. Yuniar Banoswari and I. W. S. Wicaksana, "Pengembangan Aplikasi Antar-muka Pemakai untuk Penghitungan Similaritas Semantik Berbasis String dan Wordnet," vol. 1, no. 2, pp. 10-12, 2007.

[7] R. A. Gandhi and V. B. Vaghela, "Computing textual semantic similarity for short texts using different," International Research Journal of Engineering and Technology (IRJET), vol. 4, no. 5, pp. 1207-1213, 2017.

[8] L. Meng, R. Huang and J. Gu, "Measuring Semantic Similarity of Word Pairs Using Path and Information Content," International Journal of Future Generation Communication and Networking, vol. 7, no. 3, pp. 183-194, 2014.

[9] T. Slimani, "Description and Evaluation of Semantic Similarity Measures Approaches," International Journal of Computer Applications, vol. 80, no. 10, pp. 25-33, 2013.

[10] P. Kharismadita and F. Rahutomo, "Implementasi Tokenizing Plus pada Sistem Pendeteksi Kemiripan Jurnal Skripsi," Jurnal Informasi, vol. 2, no. 1, pp. 24-28, 2015.

[11] D. Guessoum, M. Miraoni and C. Tadj, "A modification of Wu and Palmer Semantic Similarity Measure," The Tenth International Conference on Mobile Ubiquitous Computing, Systems, Services and Technologies, pp. 42-46, 2016.

[12] A. Millah and S. Nurazizah, "Perbandingan Penggunaan Algoritma Cosinus dan Wu Palmer untuk Mencari Kemiripan Kata dalam Plagiarism Checker," Jurnal Ilmu Komputer dan Desain Komunikasi Visual, vol. 2, no. 1, 2017.

[13] D. Lin, "An information-theoretic definition of similarity," in Proceeding of International, Canada, 1998.

[14] K. Shahzad, I. Pervaz, R. Muhammad and A. Nawab, "WordNet-based Semantic Similarity Measures for Process Model Matching," in International Conference on Perspectives in Business Informatics Research, Sweden, 2018.

[15] T. Slimani, "Description and Evaluation ofSemantic Similarity," International Journal of Computer Applications, vol. 80, no. 10, p. 0975 - 8887, 2013.

[16] H. Taherdoost, "Decision Making Using the Analytic Hierarchy Process (AHP); A Step by Step Approach," International Journal of Economics and Management Systems, vol. 2, pp. 244-246, 2017. 